\title{
Viral infections stimulate the metabolism and shape prokaryotic assemblages in submarine mud volcanoes
}

\author{
Cinzia Corinaldesi, Antonio Dell'Anno and Roberto Danovaro \\ Department of Life and Environmental Sciences, Università Politecnica delle Marche, Ancona, Italy
}

\begin{abstract}
Mud volcanoes are geological structures in the oceans that have key roles in the functioning of the global ecosystem. Information on the dynamics of benthic viruses and their interactions with prokaryotes in mud volcano ecosystems is still completely lacking. We investigated the impact of viral infection on the mortality and assemblage structure of benthic prokaryotes of five mud volcanoes in the Mediterranean Sea. Mud volcano sediments promote high rates of viral production $\left(1.65-7.89 \times 10^{9}\right.$ viruses $\left.\mathrm{g}^{-1} \mathrm{~d}^{-1}\right)$, viral-induced prokaryotic mortality (VIPM) $(33 \%$ cells killed per day) and heterotrophic prokaryotic production $\left(3.0-8.3 \mu \mathrm{gC} \mathrm{g}^{-1} \mathrm{~d}^{-1}\right.$ ) when compared with sediments outside the mud volcano area. The viral shunt (that is, the microbial biomass converted into dissolved organic matter as a result of viral infection, and thus diverted away from higher trophic levels) provides $49 \mathrm{mgC} \mathrm{m}^{-2} \mathrm{~d}^{-1}$, thus fuelling the metabolism of uninfected prokaryotes and contributing to the total $\mathrm{C}$ budget. Bacteria are the dominant components of prokaryotic assemblages in surface sediments of mud volcanoes, whereas archaea dominate the subsurface sediment layers. Multivariate multiple regression analyses show that prokaryotic assemblage composition is not only dependant on the geochemical features and processes of mud volcano ecosystems but also on synergistic interactions between bottom-up (that is, trophic resources) and top-down (that is, VIPM) controlling factors. Overall, these findings highlight the significant role of the viral shunt in sustaining the metabolism of prokaryotes and shaping their assemblage structure in mud volcano sediments, and they provide new clues for our understanding of the functioning of cold-seep ecosystems.
\end{abstract}

The ISME Journal (2012) 6, 1250-1259; doi:10.1038/ismej.2011.185; published online 15 December 2011 Subject Category: microbial ecology and functional diversity of natural habitats

Keywords: marine sediments; mud volcanoes; viral production; virus-prokaryote interactions

\section{Introduction}

Submarine mud volcanoes are geological structures that are formed by the eruption of mud, fluids and gases (typically methane) from deep-subsurface sediment reservoirs (Milkov, 2000). Global estimates suggest that $10^{3}-10^{5}$ mud volcanoes are distributed worldwide, mostly concentrated on the continental margins and abyssal plains (Dimitrov, 2002). Mud volcanoes are expected to have key roles in the carbon budget, biogeochemical cycles, climate regulation, biomass production and maintenance of biodiversity, thus providing essential 'goods and services' for global ecosystems (Niemann et al., 2006; Jørgensen and Boetius, 2007).

The emission of methane and other hydrocarbons, the presence of gas hydrates, and the release of high

Correspondence: C Corinaldesi, Department of Life and Environmental Sciences, Università Politecnica delle Marche, Via Brecce Bianche, 60131 Ancona, Italy.

E-mail: c.corinaldesi@univpm.it

Received 22 May 2011; revised 7 November 2011; accepted 11 November 2011; published online 15 December 2011 concentrations of sulphides sustain an enormous microbial biomass (Pimenov et al., 1997; Boetius and Suess, 2004; Joye et al., 2004). At present, we know that microbial assemblages in cold-seep ecosystems are typically dominated by sulphatereducing bacteria and methanotrophic archaea, which mediate anaerobic oxidation of methane with sulphate (Jørgensen and Boetius, 2007). This process represents one of the major global sinks for methane (Michaelis et al., 2002; Niemann et al., 2006; Pachiadaki et al., 2010).

Although viruses dominate all of the ecosystems on the Earth numerically (outnumbering prokaryotes by about 10-fold; Suttle, 2005; Danovaro et al., 2008a) and they are a major cause of mortality for a wide range of marine organisms (Fuhrman, 1999; Suttle, 2005), their role in ecosystems characterised by seepage is still unclear. Information available from both shallow-water hydrothermal vents (Mediterranean Sea and Pacific Oceans; Manini et al., 2008) and cold seeps (Sagamy Bay, Japan, and Gulf of Mexico; Middelboe et al., 2006; Kellogg, 2010; respectively) suggests that these environments can be either 'hot-spots' or 'cold-spots' of viral activity 
(that is, enhanced or reduced viral activity at seep sites, as compared with surrounding sediments). However, information on the dynamics of benthic viruses and their interactions with prokaryotes in mud volcano ecosystems is still completely lacking.

Recent studies carried out in marine sediments worldwide have indicated that the viral shunt, which was originally described for pelagic systems (Wilhelm and Suttle, 1999), is also an essential source of organic detritus in benthic ecosystems. Here, viral lysis of the infected microbes transforms the cell contents and biomass into organic detritus, which contribute greatly to the metabolism of noninfected prokaryotes (Danovaro et al., 2008b).

Here, we report the results of the first investigation conducted on viral production and decay, viral impact on prokaryotic mortality, and the contribution of the viral shunt to $\mathrm{C}$ cycling in five mud volcanoes of the Mediterranean Sea. We also explore the role of viral infection in controlling prokaryotic assemblage structure in these ecosystems.

\section{Methods}

Study site and sampling strategy

Sediment samples were collected in the Sicily Channel (Western Mediterranean; Figure 1) from February to July, 2007. The region under investigation has about 175 mud volcanoes and a venting area of about $0.1 \mathrm{~km}^{2}$ (Holland et al., 2003). The sampling strategy included a set of seven sampling areas, five of which were located in mud volcanoes (MV02, MV03, MV04, MV05 and MV06), with two areas located along the slope at similar depths and without gas emissions (hereafter defined as the controls: CTRL1 and CTRL2; Figure 1). The geophysical survey led to the defining of two main geomorphological structures: (i) terrace-like carbonate structures (hereafter referred to as ridges), which consist of large tabular sub-elongated structures that are elevated up to $5 \mathrm{~m}$ to $10 \mathrm{~m}$ from the sea floor, and which have flat tops that are surmounted by several carbonate structures; and (ii) domeshaped structures that are isolated or in clusters and are $50 \mathrm{~m}$ to $200 \mathrm{~m}$ wide and up to $5 \mathrm{~m}$ high. A detailed description of mud volcano areas was reported by Savini et al. (2009). Seawater samples were collected within $5 \mathrm{~m}$ of the seabed at the MV04, MV05 and MV06 stations, using Niskin bottles. The gas (methane) dissolved in these samples was analysed by gas chromatography (Carle AGC 100-400 TCD-FID GC) at Isotech Labs Inc. (Champaign, IL, USA). At each site, three undisturbed sediment cores were collected using a NIOZ-type box-corer, which allows collection of samples that can be hermetically closed. Immediately after sampling, sediment sub-aliquots were collected for a

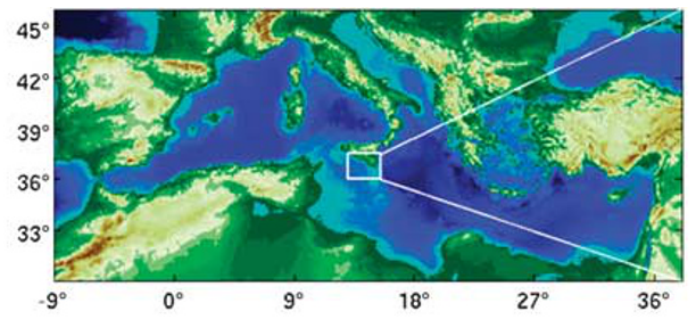

b

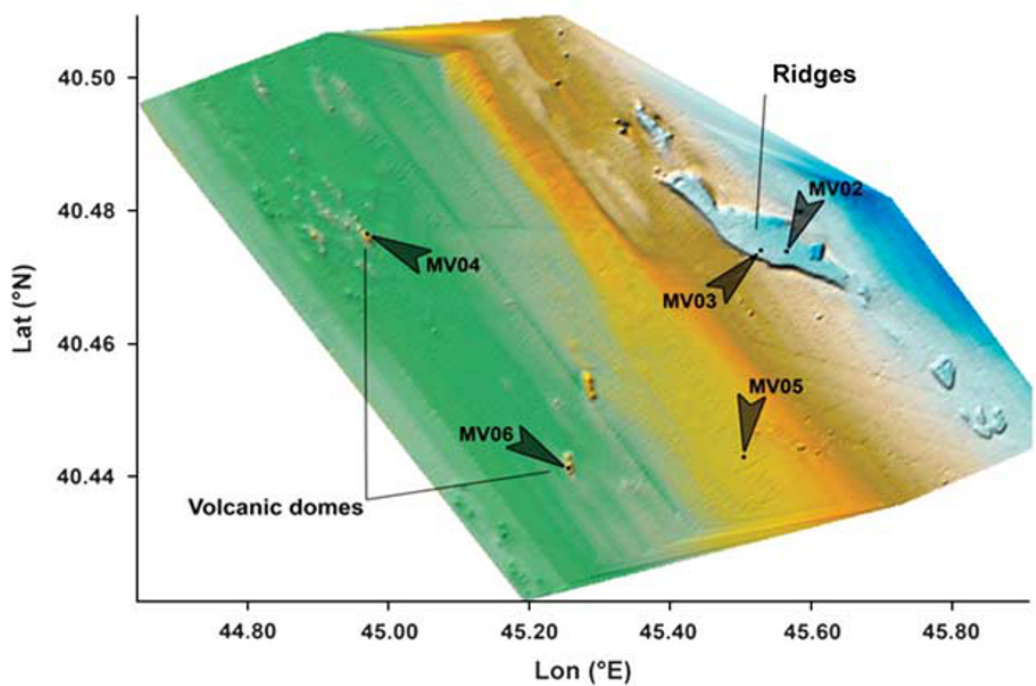

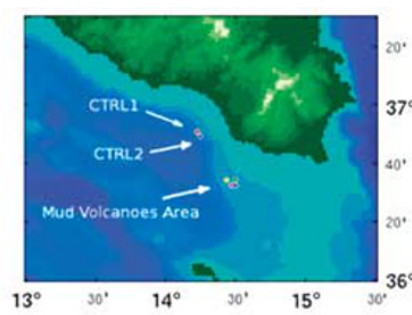

Depth (m)

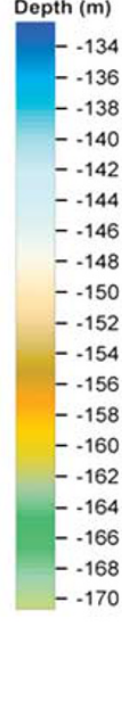

Figure 1 (a) Map of the Sicily channel (Mediterranean Sea) with the location of the sampling stations. (b) Digital elaboration of the seafloor geomorphology obtained by side-scan sonar and multibeam data. Arrows indicate the sampling stations. 
analysis of the biochemical composition of the organic matter and for microbiological parameters. For analyses of the biochemical composition of the organic matter in the sediments (in terms of protein, carbohydrate, lipid and total phytopigment), the samples were stored at $-20^{\circ} \mathrm{C}$.

To provide accurate estimates of viral abundance, production and decay, the surface $(0-1 \mathrm{~cm})$ and subsurface $(10-15 \mathrm{~cm})$ layers from each sediment core were immediately processed onboard, without the addition of any preservative (Danovaro et al., 2001; Dell'Anno et al., 2009). This was because it is widely recognised that the use of formaldehyde or glutaraldehyde for sample storage can result in a rapid loss of viruses in sediment samples (Helton et al., 2006; Dell'Anno et al., 2009).

For the prokaryotic counts, samples from these surface $(0-1 \mathrm{~cm})$ and sub-surface $(10-15 \mathrm{~cm})$ layers of each sediment core were fixed with buffered $2 \%$ formalin and stored at $4{ }^{\circ} \mathrm{C}$ until processed (within two weeks; Danovaro et al., 2002). For analysis of prokaryotic heterotrophic $\mathrm{C}$ production, additional subsamples from the top first $1 \mathrm{~cm}$ were processed immediately after retrieval, as described below. For analysis of the prokaryotic assemblage structure by catalysed reporter deposition-fluorescence in situ hybridisation (CARD-FISH), the surface (top $1 \mathrm{~cm}$ ) and subsurface (10-15 cm layer) sediment aliquots of each core were fixed with $2 \%$ paraformaldehyde (polymerised formaldehyde, dry chemical), washed with phosphate-buffered saline solution $(137 \mathrm{mM}$ $\mathrm{NaCl}, 2.7 \mathrm{mM} \mathrm{KCl}, 10 \mathrm{mM} \mathrm{Na} \mathrm{HPO}_{4}, 2 \mathrm{mM} \mathrm{KH} \mathrm{PO}_{4}$, $\mathrm{pH}$ 7.6), and then stored in phosphate-buffered saline solution: $96 \%$ ethanol $(1: 1)$ at $-20^{\circ} \mathrm{C}$ until further processing (Pernthaler et al., 2004).

\section{Biochemical composition of organic matter}

The concentrations of proteins, carbohydrates and lipids in the sediment were determined spectrophotometrically, according to Danovaro (2010), and expressed as bovine serum albumin, glucose and tripalmitine equivalents, respectively. The sum of the carbohydrate, protein and lipid concentrations converted into carbon equivalents (using the conversion factors of $0.40,0.49$ and $0.75 \mu \mathrm{gC} \mu \mathrm{g}^{-1}$, respectively) was defined as the biopolymeric organic carbon (Pusceddu et al., 2009). Chlorophyll- $a$ and phaeopigment concentrations were determined fluorometrically, according to Danovaro (2010). Total phytopigments were defined as the sum of chlorophyll- $a$ and phaeopigments, and their concentrations are reported as $\mu \mathrm{gg}^{-1}$. Details of the analyses of the biochemical composition of the organic matter are reported in the Supplementary Materials.

\section{Viral abundance}

Viral counting was carried out as described by Danovaro et al. (2001). Sediment sub-samples $\left(0.5 \mathrm{~cm}^{3}\right.$ of wet sediment) were diluted in an equal volume of virus-free seawater (filtered at $0.02 \mu \mathrm{m}$ pore size using disposable syringe filters; Anotop 25, Whatman; dilution 1:1, v:v), and treated with pyrophosphate (final concentration, $5 \mathrm{mM}$ ) and ultrasound (three times, for $1 \mathrm{~min}$ each; Branson 2200 sonicator, $60 \mathrm{~W}$ ) to increase the extraction yields. The samples were then diluted 100-500-fold in virus-free water and filtered onto $0.02 \mu \mathrm{m}$ pore size filters (Anodisc $\mathrm{Al}_{2} \mathrm{O}_{3} ; 25 \mathrm{~mm}$ diameter, Whatman). Then the filters were stained using SYBR Green I $(10000 \times$ in anhydrous dimethyl sulphoxide; Molecular Probes-Invitrogen, Grand Island, NY, USA), incubated in the dark for $20 \mathrm{~min}$, and then mounted on glass slides with a drop of $50 \%$ phosphate buffer $(6.7 \mathrm{mM}, \mathrm{pH} 7.8)$ and $50 \%$ glycerol containing $0.5 \%$ ascorbic acid (Noble and Fuhrman, 1998). Viral counting was performed under epifluorescence microscopy (Zeiss Axioskop 2; magnification, $\times 1000$; filter set \#9, excitation BP 450-490, beam splitter FT 515, emission LP 520), by examining at least 10 fields per slide, and counting at least 400 viral particles per filter. The viral abundance was expressed as viruses per g dry sediment (after desiccation at $60{ }^{\circ} \mathrm{C}$ for $24 \mathrm{~h}$ ).

\section{Prokaryotic abundance}

For prokaryotic counting, $c a .1 \mathrm{~cm}^{3}$ of sediment from the top $1 \mathrm{~cm}$ and from the $10-15 \mathrm{~cm}$ layer of each sediment core were analysed as previously described by Danovaro et al. (2002). Three replicate sediment sub-samples were each suspended in tetrasodium pyrophosphate (final concentration, $5 \mathrm{mM}$ ) and sonicated three times (Branson Sonifier 2200; $60 \mathrm{~W}$ for $1 \mathrm{~min})$. The samples were then diluted with sterile seawater that was pre-filtered through $0.2-\mu \mathrm{m}$-pore-size filters $(25 \mathrm{~mm}$ diameter disposable syringe filters; Whatman). Following filtering onto $0.2 \mu \mathrm{m}$ pore size filters (Anodisc $\mathrm{Al}_{2} \mathrm{O}_{3}, 25 \mathrm{~mm}$ diameter; Whatman), the samples were stained using SYBR Green I $(10000 \times$ concentrate in anhydrous dimethyl sulphoxide; Molecular Probes-Invitrogen), and the filters were incubated in the dark for $20 \mathrm{~min}$ and mounted on microscope slides with $20 \mu \mathrm{l} 50 \%$ phosphate buffer ( $\mathrm{pH} 7.8$ ) and $50 \%$ glycerol containing $0.5 \%$ ascorbic acid. Total prokaryotic counts were obtained under epifluorescence microscopy (Zeiss Axioskop 2, magnification $\times 1000$, filter set \#9, excitation BP 450-490, beam splitter FT 515, emission LP 520) by examining at least 10 fields per slide, to count at least 200 cells per filter. The data were normalised to sediment dry weight after desiccation $\left(60^{\circ} \mathrm{C}, 24 \mathrm{~h}\right)$.

\section{Viral production and decay}

Viral production in the sediments was determined as described by Dell'Anno et al. (2009). Three replicate sediment samples of about $25 \mathrm{ml}$ were transferred into sterile tubes and mixed with $25 \mathrm{ml}$ 
virus-free seawater. Subsamples $(0.5 \mathrm{ml})$ were collected for viral counts at $0,1.5,3,6$ and $12 \mathrm{~h}$. As the increases in viral abundance were not linear over the first $12 \mathrm{~h}$ of incubation, in all of the samples, the net viral production was determined as the maximum increment of viral abundance per g dry sediment per $\mathrm{h}$.

Viral decay was defined as the rate of disappearance of free viruses (Danovaro et al., 2008a), and this was determined following the same procedure used for the analysis of viral production, by monitoring the decrease of viruses over time according to Corinaldesi et al. (2010). Sediment subsamples (1:1, sediment:virus-free seawater) were collected at $0,1.5,3,6,12$ and $24 \mathrm{~h}$. The measurements of viral decay were started only when a significant decrease in the viral abundance was evident, that is, generally 6-12 $\mathrm{h}$ after the beginning of the experiment. Viral decay rates were estimated as the maximum rate of decrease of the viral abundance during the timecourse experiments. The viral decay rate was expressed as the number of viruses per g dry sediment per h. Gross viral production was estimated as the sum of the net viral production and decay rates.

\section{Prokaryotic heterotrophic production}

Prokaryotic heterotrophic production was measured using $\left[{ }^{3} \mathrm{H}\right]$-leucine incorporation, following the procedure previously described by Danovaro et al. (2002). Sediment sub-samples $(200 \mu \mathrm{l})$ were supplemented with an aqueous solution of $\left[{ }^{3} \mathrm{H}\right]$-leucine $(0.2 \mathrm{nmol}$ final concentration, specific activity, $72 \mathrm{Ci} \mathrm{mmol}^{-1}$ ), and incubated for $1 \mathrm{~h}$ in the dark at the in situ temperature. Three sediment blanks were run in parallel, adding ethanol immediately before the $\left[{ }^{3} \mathrm{H}\right]$-leucine addition. After the incubation, the samples were supplemented with ethanol (80\%) and stored at $4{ }^{\circ} \mathrm{C}$ until they were processed in the laboratory. Briefly, the sediments were washed two times with ethanol $(80 \%)$ by mixing, centrifuging at $14000 \mathrm{~g}$ for $5 \mathrm{~min}$, and discarding the supernatant. The sediment was then re-suspended in $80 \%$ ethanol and transferred onto a polycarbonate membrane filter $(0.2 \mu \mathrm{m}$ pore size, Nucleopore, $25 \mathrm{~mm}$ diameter) using a filtration apparatus and a vaccum pump (Millipore, Billerica, MA, USA, <100 mm Hg). Subsequently, each filter was washed four times with $2 \mathrm{ml} 5 \%$ trichloroacetic acid, and then each filter was transferred into a pyrex test-tube containing $2 \mathrm{ml} 2 \mathrm{M} \mathrm{NaOH}$ and heated to $100{ }^{\circ} \mathrm{C}$ for $2 \mathrm{~h}$. After centrifugation at $800 \mathrm{~g}$ to separate the sediment residue, $1 \mathrm{ml}$ supernatant was transferred to scintillation vials containing an appropriate scintillation fluid. The incorporated radioactivity (as disintegration per minute) in the sediment samples was measured by determining the counts per minute in a liquid scintillation counter (Packard Tri-Carb 300). The data were normalised to sediment dry weight after desiccation $\left(60^{\circ} \mathrm{C}, 24 \mathrm{~h}\right)$.
Burst size and VIPM

Prokaryotic burst size (the number of viruses released by cell lysis due to viral infection) was calculated as the ratio of viral production to cells killed (Danovaro et al., 2008b). The number of prokaryotes killed by the viruses was estimated by time-course experiments on the basis of the expected number of prokaryotes produced (calculated as prokaryotic turnover multiplied by prokaryotic abundance) and the number of prokaryotes actually counted over the same time interval (Corinaldesi et al., 2007).

VIPM was calculated as follows:

$$
\mathrm{VIPM}=(\mathrm{KP}) * 100 / \mathrm{TP}
$$

where: KP is the number of prokaryotes killed by the viruses per g sediment per $h$, and TP is the total prokaryotic abundance per g sediment.

\section{Catalysed reporter deposition-fluorescence in-situ hybridisation}

The analysis of the benthic prokaryotic assemblage structure at the domain level (Bacteria vs Archaea) as performed by CARD-FISH, as previously described (Teira et al., 2004; Schippers et al., 2005; Danovaro et al., 2009). Methodological details are reported in the Supplementary Materials.

\section{Statistical analyses}

To test for differences in all of the variables investigated between the sampling sites, one-way analysis of variance was applied using the GMAV 5.0. software (University of Sidney, Australia), after testing for the homogeneity of variances using the Cochran test. When significant differences were encountered, Tukey's post-hoc comparison tests (at $\alpha=0.05$ ) were also carried out, to determine in which station(s) the parameters investigated were significantly different.

Multivariate multiple regression analysis was also used for investigation of the biotic and abiotic factors that influence viral distribution and prokaryotic assemblage composition. All of the analyses were carried out with routine distance-based multivariate analysis for a linear model forward (Anderson, 2004). The $P$-values were obtained using 4999 permutations of residuals under the reduced model (Anderson, 2001).

\section{Results}

Methane concentrations and biochemical composition of organic matter

The methane, biopolymeric $\mathrm{C}$, and phytopigment concentrations are reported in Table 1 . Both the domes and ridges are influenced by methane seeps, with the highest concentrations of methane dissolved in the seawater at the MV05 station. 
Table 1 Site description and concentrations of methane, BPC and total phytopigments in the different areas investigated

\begin{tabular}{|c|c|c|c|c|c|c|c|}
\hline $\begin{array}{l}\text { Sampling } \\
\text { areas }\end{array}$ & Geomorphology & Latitude (N) & Longitude (E) & Depth (m) & $\mathrm{CH}_{4}(\% ; \mathrm{v} / \mathrm{v})$ & $B P C\left(m g C g^{-1}\right)$ & $\begin{array}{c}\text { Phytopigments } \\
\left(\mu g g^{-1}\right)\end{array}$ \\
\hline MV02 & Ridge & $36^{\circ} 34^{\prime} 16^{\prime \prime}$ & $14^{\circ} 30^{\prime} 09^{\prime \prime}$ & 141 & n.a. & $0.62 \pm 0.07$ & $33.4 \pm 10.5$ \\
\hline MV03 & Ridge & $36^{\circ} 34^{\prime} 14^{\prime \prime}$ & $14^{\circ} 29^{\prime} 58^{\prime \prime}$ & 143 & n.a. & $0.59 \pm 0.08$ & $28.0 \pm 7.0$ \\
\hline MV04 & Clustered domes & $36^{\circ} 34^{\prime} 22^{\prime \prime}$ & $14^{\circ} 26^{\prime} 20^{\prime \prime}$ & 163 & 0.05 & $0.45 \pm 0.08$ & $24.0 \pm 11.0$ \\
\hline MV05 & Isolated dome & $36^{\circ} 32^{\prime} 35^{\prime \prime}$ & $14^{\circ} 29^{\prime} 50^{\prime \prime}$ & 159 & 0.17 & $0.58 \pm 0.05$ & $14.7 \pm 8.4$ \\
\hline MV06 & Dome with moats & $36^{\circ} 32^{\prime} 27^{\prime \prime}$ & $14^{\circ} 28^{\prime} 13^{\prime \prime}$ & 164 & 0.05 & $0.27 \pm 0.04$ & $12.6 \pm 2.9$ \\
\hline CTRL 1 & Slope & $36^{\circ} 50^{\prime} 39^{\prime \prime}$ & $14^{\circ} 13^{\prime} 35^{\prime \prime}$ & 217 & 0 & $2.46 \pm 0.19$ & $4.4 \pm 2.6$ \\
\hline CTRL 2 & Slope & $36^{\circ} 49^{\prime} 27^{\prime \prime}$ & $14^{\circ} 15^{\prime} 11^{\prime \prime}$ & 222 & 0 & $3.25 \pm 1.15$ & $3.8 \pm 0.8$ \\
\hline
\end{tabular}

Abbreviations: BPC, biopolymeric carbon; n.a., not available. s.d. $( \pm)$ are reported.

Biopolymeric C concentrations (used as a proxy for the available trophic resources; Pusceddu et al., 2009) in the surface sediments ranged from $0.27 \pm 0.04$ to $3.25 \pm 1.15 \mathrm{mgCg}^{-1}$ (at stations MV06 and CTRL2, respectively), while the total phytopigment concentrations varied from $3.8 \pm 0.8 \mu \mathrm{gg}^{-1}$ to $33.4 \pm 10.5 \mathrm{\mu g} \mathrm{g}^{-1}$ (at stations CTRL2 and MV02, respectively).

Viral and prokaryotic abundance

Viral abundance in the surface sediments $(0-1 \mathrm{~cm}$ layer) ranged from $5.42 \pm 1.53 \times 10^{8}$ to $31.87 \pm 1.24 \times 10^{8}$ viruses $\mathrm{g}^{-1}$ (at stations CTRL1 and MV05, respectively; Figure 2a), and it was significantly higher in the mud volcanoes than in the control stations (analysis of variance, $P<0.01$ ). At all of the stations, the viral abundance decreased significantly in the subsurface sediment layers (range, $3.63 \pm 0.61 \times 10^{8}$ to $9.85 \pm$ $1.28 \times 10^{8}$ viruses $^{-1}$, at the $10-15 \mathrm{~cm}$ sediment depth at stations MV06 and MV02, respectively, $P<0.05$, Figure 2a).

Prokaryotic abundance in the surface sediments (0-1 cm layer; Figure 2b) ranged from 1.89 \pm $0.30 \times 10^{8}$ cells g $^{-1}$ to $11.31 \pm 2.01 \times 10^{8}$ cells g $^{-1}$ (at stations CTRL1 and MV02, respectively), and on average, it was significantly higher for the mud volcanoes than for the control stations $\left(7.37 \times 10^{8} \mathrm{vs}\right.$ $3.02 \times 10^{8}$ cells g $^{-1}, P<0.01$ ).

In the subsurface sediments $(10-15 \mathrm{~cm}$ layer), the prokaryotic abundance (range, $0.60 \pm 0.14-5.22 \pm$ $0.65 \times 10^{8}$ cell g$^{-1}$ at stations MV06 and MV02, respectively) was significantly lower than in the surface sediments $(P<0.05)$. The virus to prokaryote abundance ratio ranged from 1.6 to 7.9 in the surface sediments (at stations MV02 and MV05, respectively), and from 1.9 to 10.6 in the subsurface sediments (at stations MV02 and MV05, respectively; Figure 2c).

Viral production and decay, and VIPM

The net viral production in the surface sediments ranged from $0.25 \pm 0.02 \times 10^{8}$ to $3.29 \pm 0.43 \times 10^{8}$ virus $\mathrm{g}^{-1} \mathrm{~h}^{-1}$ (at stations CTRL1 and MV03, respectively). Significant differences were observed among the stations, with viral production higher in the mud volcano sediments than in the control sediments $(P<0.05$; Figure 3a).

Viral decay ranged from $0.37 \pm 0.09 \times 10^{7}$ to $8.83 \pm 2.91 \times 10^{7}$ viruses $g^{-1} \mathrm{~h}^{-1}$ (at stations CTRL1 and MV04, respectively; Figure 3b). The mud volcano sediments were characterised by viral decay rates (on average, $5.25 \times 10^{7}$ viruses $\mathrm{g}^{-1} \mathrm{~h}^{-1}$ ) that were significantly higher than in the control sediments (on average, $0.87 \times 10^{7}$ viruses $\mathrm{g}^{-1} \mathrm{~h}^{-1}$; $P<0.01$ ). Viral decay accounted for $22 \%$ of the gross production in the mud volcano sediments, and $25 \%$ in the control sediments.

VIPM in the mud volcano stations, except for MV02, was significantly higher than in the control stations $(P<0.01$; on average, $33 \%$ vs $23 \%$ killed prokaryotes per day in mud volcano and control sediments, respectively; Figure 3c).

Prokaryotic heterotrophic $C$ production and biomass Prokaryotic heterotrophic $\mathrm{C}$ production in surface sediments ranged from $43.0 \pm 12.4$ to $346.6 \pm$ $54.9 \mathrm{ngCg}^{-1} \mathrm{~h}^{-1}$ (at stations CTRL1 and MV03, respectively) and was $c a$. 6-fold higher in the mud volcano sediments than in the control sediments (Figure 4a). The prokaryotic biomass in the surface sediments ranged from $4.5 \pm 0.7$ to $33.5 \pm 8.6 \mu \mathrm{gCg}^{-1}$ (at stations CTRL1 and MV02, respectively), and on average, for the mud volcanoes it was $c a$. three-fold higher than in the control sediments (21.6 vs $6.5 \mu \mathrm{gCg}^{-1}$, respectively; Figure $4 \mathrm{~b}$ ). The turnover rates of prokaryotic biomass ranged from $0.18 \mathrm{~d}^{-1}$ to $0.33 \mathrm{~d}^{-1}$ (at stations MV02 and MV03, respectively), and on average, they were similar between the mud volcanoes and the control sediments $(0.28$ vs $0.25 \mathrm{~d}^{-1}$, respectively; see Supplementary Figure S1).

\section{Prokaryotic assemblage structure}

The number of benthic prokaryotes detected using CARD-FISH (that is, the total bacterial abundance plus the total archaeal abundance) accounted for, on average, $73 \%$ of the total prokaryotic abundance as determined using SYBR Green I. 


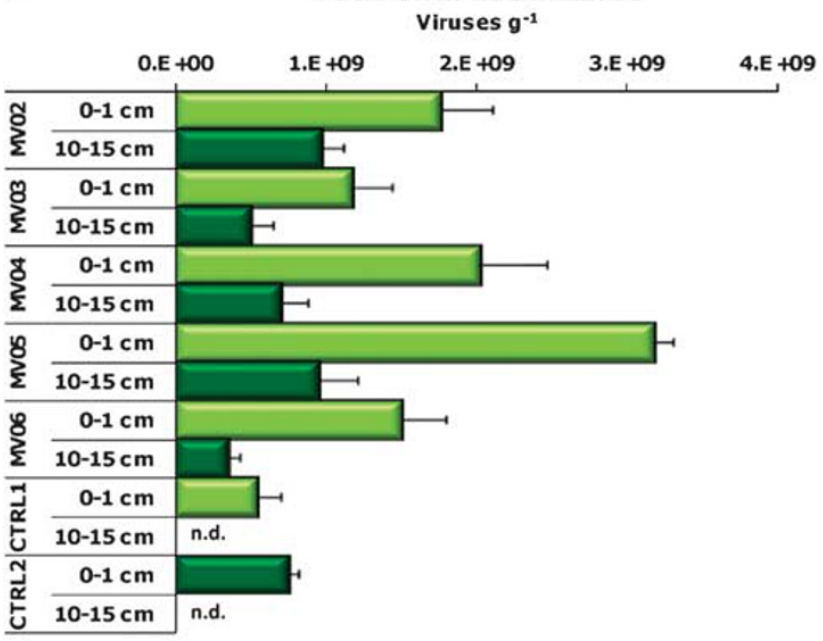

b

Total prokaryotic abundance

Prokaryotes $\mathbf{g}^{-1}$

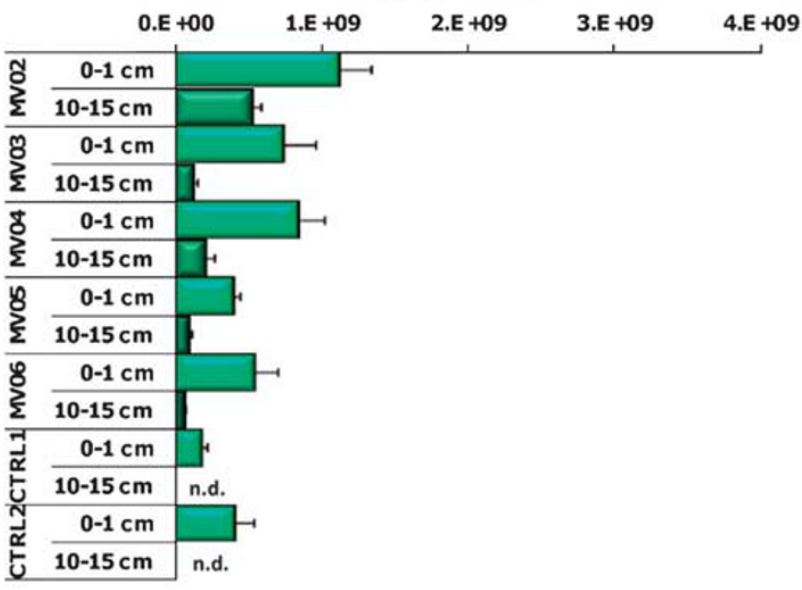

C

Virus to prokaryote abundance ratio VPR

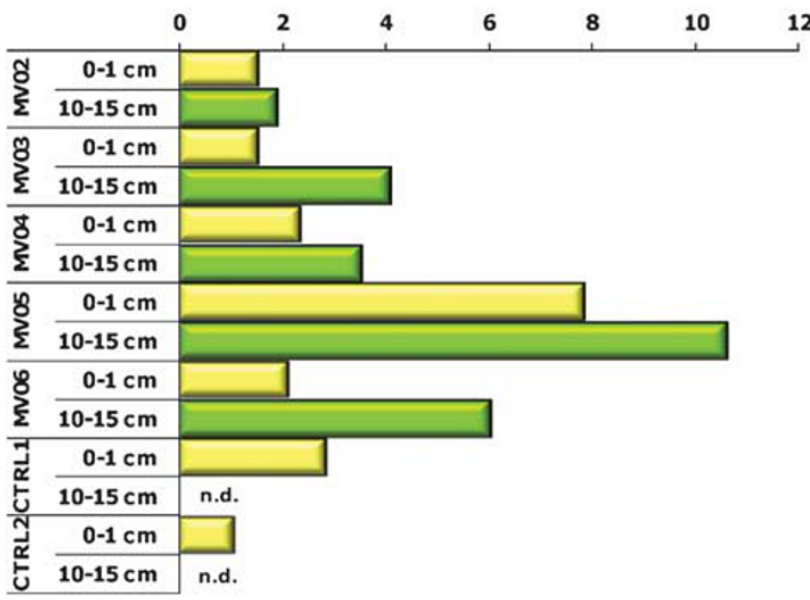

Figure 2 (a) Total viral abundance; (b) total prokaryotic abundance; and (c) viral-to-prokaryotic abundance ratio in surface $(0-1 \mathrm{~cm})$ and subsurface $(10-15 \mathrm{~cm})$ sediments of the mud volcano and the control stations. nd, not determined.

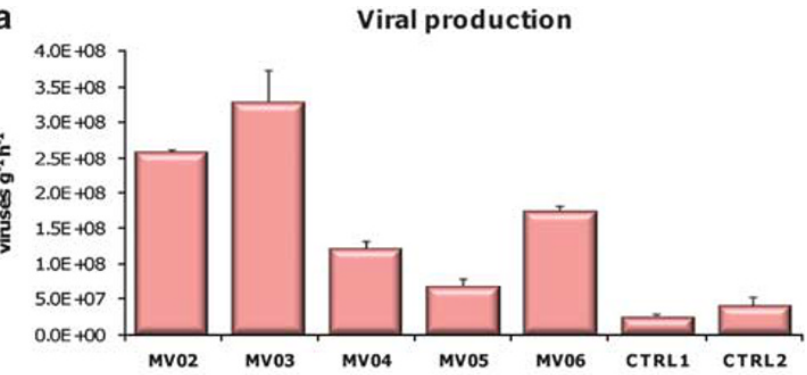

b

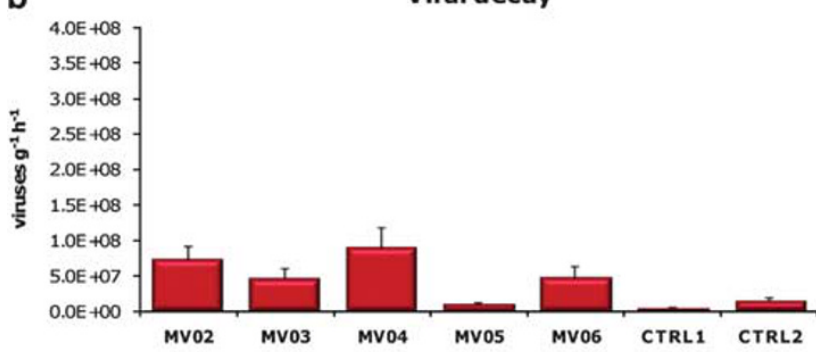

C

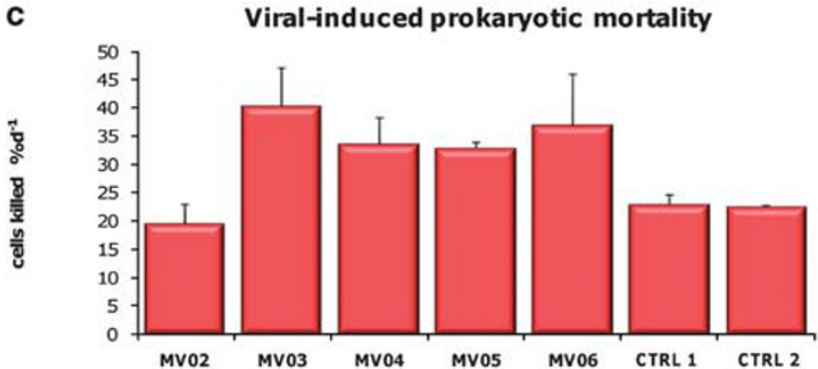

Figure 3 (a) Viral production; (b) viral decay; and (c) VIPM in the surface sediments $(0-1 \mathrm{~cm})$. s.d. are shown.

a Prokaryotic heterotrophic $\mathrm{C}$ production

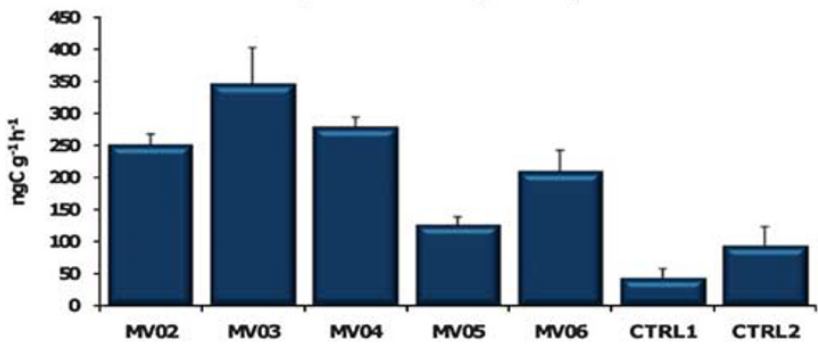

b

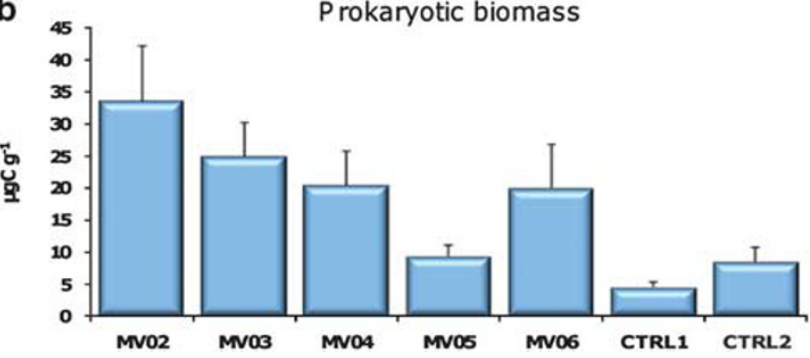

Figure 4 Prokaryotic heterotrophic C production (a) and biomass (b) in the surface sediments $(0-1 \mathrm{~cm})$. s.d. are shown. 


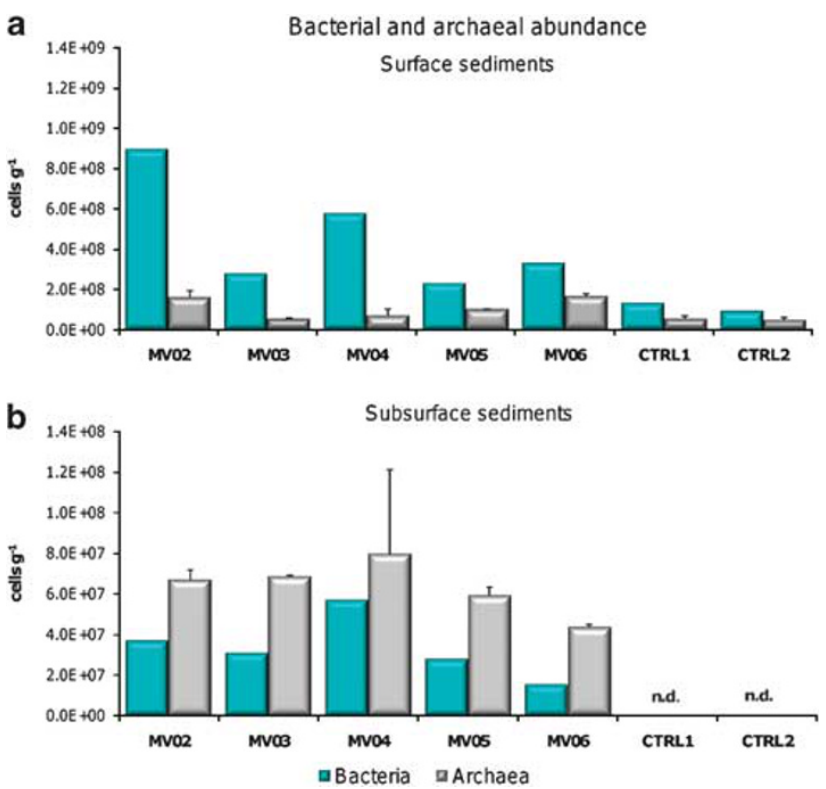

Figure 5 Abundances of bacteria and archaea in surface (a) and subsurface sediments (b). nd, not determined.

The abundance of bacteria and archaea was significantly higher in the surface sediments of the mud volcanoes than in the control sediments (on average, $4.65 \times 10^{8}$ vs $1.16 \times 10^{8}$ cells g $^{-1}$ for bacteria, and $1.13 \times 10^{8}$ vs $0.54 \times 10^{8}$ cells g $^{-1}$ for archaea; $P<0.01$; Figure 5a). The abundance of Archaea increased with the depth of the sediment, and was $c a$. double the abundance of bacteria (on average, $6.37 \times 10^{7}$ vs $3.38 \times 10^{7}$ cells g $^{-1}$, respectively; Figure 5b).

Within the archaeal domain, the contributions of crenarchaea and euryarchaea were similar in surface sediments of mud volcanoes (on average, $c a .10 \%$ of the total cell counts by CARD-FISH; see Supplementary Figure S2a). Conversely, the abundance of crenarchaea was $c a$. three-fold higher than that of euryarchaea in the control sediments (on average, $23.3 \%$ vs $8.3 \%$ ).

Crenarchaea accounted for a significantly lower fraction than for euryarchaea in the subsurface sediments of the mud volcanoes (on average, 3.3\% vs $32.1 \%$; Figure S2b).

\section{Discussion}

The impact of viruses on prokaryotic activity

Viral abundance in mud volcano sediments was significantly higher than that determined in the control sediments, with values similar to that previously reported in cold seeps of the Gulf of Mexico (Kellogg, 2010), although much higher than that observed in a cold seep of Sagami Bay (Japan, Middelboe et al., 2006).

The determination of viral and prokaryotic abundance alone does not provide information on the dynamics of benthic viruses and their effects on prokaryotic assemblages (Danovaro et al., 2008b). We thus also investigated viral production, decay and impact on prokaryotes. Viral production in the mud volcano sediments was high and comparable to values reported for highly productive benthic coastal ecosystems (Danovaro et al., 2008a). In addition, viral production in the mud volcanoes investigated was significantly higher (up to one order of magnitude) than that of the control sediments. Recent studies have indicated that lysogenic infection can prevail on the lytic strategy both in shallow and deep hydrothermal vent ecosystems (Williamson et al., 2008; Maugeri et al., 2010). However, our results suggest that the environmental conditions of mud volcanoes promote high rates of viral replication through lytic infection, which indicates that these ecosystems represent hot spots of viral activity.

Viral production co-varied with the metabolic activity of the prokaryotes (prokaryotic $\mathrm{C}$ production: $n=15, \quad r=0.89, P<0.01$ ), which was, on average, $c a$. six-fold higher in the mud volcano sediments than in the control sediments. The high heterotrophic prokaryotic $\mathrm{C}$ production in mud volcano sediments was associated with high concentrations of organic $\mathrm{C}$ derived from primary production processes (that is, the phytopigment content was $c a$. six-fold higher than in the control sediments).

The viral impact on prokaryotes in the mud volcano sediments was, on average, higher than in the control sediments (33\% and $23 \%$ of prokaryotes killed per day, respectively), and was even higher when compared with prokaryotic mortality previously reported for marine sediments at similar depths worldwide (Danovaro et al., 2008b). This suggests that viral infection has crucial implications in the functioning of mud volcano ecosystems. We also found that viral and prokaryotic abundance in subsurface sediments (the $10-15 \mathrm{~cm}$ layer) was significantly lower than in the surface sediments (the $0-1 \mathrm{~cm}$ layer). However, viral abundance decreased with depth in the sediment to a lesser extent than prokaryotic abundance. Consequently, the virus-to-prokaryote abundance ratios in the subsurface sediments were up to 3-fold higher than in surface sediments. This pattern allows us to hypothesise that the viral impact on their hosts in these subsurface sediments is even greater than in the surface sediments (Corinaldesi et al., 2010). Overall, these findings suggest that the environmental conditions in mud volcanoes sustain high prokaryotic heterotrophic metabolism, and promote highly dynamic virus-prokaryote interactions.

\section{Factors influencing the viral shunt in mud volcano sediments}

Viral abundance in marine sediments is generally related to viral production (Danovaro et al., 2008a), 
although this was not the case for the present study, as the patterns of viral abundance in the mud volcano sediments were opposite to those of the viral production. In particular, the highest viral abundance and the lowest viral production rates were observed in the mud volcano sediments that were characterised by the highest gas emission (MV05, viral abundance one third of that in the other mud volcano stations). The uncoupled patterns between viral abundance and production can be dependant upon viral decay rates (Corinaldesi et al., 2010). Indeed, at the MV05 station, we found the lowest viral decay rate and contribution to the gross viral production (12\%).

Statistical multivariate analyses reveal also that $c a .95 \%$ of the total variance of the viral abundance was explained by the biopolymeric carbon and methane concentrations, which can influence the viral distribution by stimulation of the metabolism of their host and/or by supplying mud volcano sediments with viruses not produced in situ.

We conclude here that the main factors driving the highly dynamic viral assemblages in mud volcanoes are different and more complex than those in sediments without seepage.

The viral shunt fuels the metabolism of benthic prokaryotes and influences their assemblage structure Viral lysis of prokaryotic cells results in the release of cellular detritus, which can be an important organic source for prokaryotic metabolism (Corinaldesi et al., 2007; Suttle, 2007; Danovaro et al., 2008a,b). In mud volcano sediments, we estimated that the $\mathrm{C}$ released by viral lysis was, on average, $47 \mathrm{mg} \mathrm{C} \mathrm{m}^{-2} \mathrm{~d}^{-1}$. This is $c a$. four-fold higher than that released in the control sediments, which in turn is similar to values reported for other benthic systems at similar depths worldwide (Danovaro et al., 2008a,b). If we also include the organic $C$ released by viral decay in the $\mathrm{C}$ flux derived from viral-shunt processes, the amount of $\mathrm{C}$ derived by viral lysis in the mud volcano sediments was, on average, $49 \mathrm{mg} \mathrm{C} \mathrm{m}^{-2} \mathrm{~d}^{-1}$. Assuming a conservative value of $\mathrm{C}$ conversion efficiency in prokaryotic biomass of $20 \%$ (del Giorgio and Cole, 1998), the amount of $C$ released by viral lysis accounts for $c a .21 \%$ of the prokaryotic $\mathrm{C}$ demand in the mud volcano sediments. Such values are comparable to those previously reported in different marine pelagic systems $(5-30 \%$ of the prokaryotic carbon demand; Wilhelm and Suttle, 1999; Bonilla-Findji et al., 2008).

Recent studies have suggested that viral lysis of microorganisms is also a source of recalcitrantdissolved organic carbon, and as this is resistant to microbial degradation, it can persist in the ocean interior for thousands of years (Jiao et al., 2010).

Overall, these findings suggest that the total $\mathrm{C}$ released by viral lysis in mud volcano sediments can sustain prokaryotic assemblages through stimulation of the metabolism of non-infected prokaryotes, and it can represent a carbon source that fuels the dissolved organic carbon pool of the overlying water column.

Information on the impact of viral infection on prokaryotic biodiversity and community structure in benthic ecosystems is still largely lacking (Hewson and Fuhrman, 2007). In the present study, we found that bacteria are the dominant component of prokaryotic assemblages both in surface sediments of mud volcanoes and in the controls. Conversely, in the subsurface sediments of mud volcanoes, archaea account for $c a$. $60 \%$ of prokaryotic abundance, on average. The increase in the relative importance of archaea with increasing depth in sediments has already been reported for continental margins (Biddle et al., 2006; Lipp et al., 2008) and other mud volcano ecosystems (Lösekann et al., 2007), which suggests that this component is more adapted than bacteria to live and grow under the environmental conditions occurring in the mud volcano subsurface.

Previous studies have suggested that crenarchaea typically dominate over euryarchaea in oxygenated deep waters (De Long et al., 1999; Karner et al., 2001) and surface sediments (Vetriani et al., 1999; Danovaro et al., 2009). We found the same pattern in the control sediments, whereas euryarchaea were dominant in the surface and subsurface sediments of the mud volcanoes. The dominance of euryarchaea over crenarchaea has been previously reported for gas-hydrate-bearing and methane-bearing sediments, and this was related to the exploitation of the methane released by the seeps (Inagaki et al., 2006; Parkes et al., 2007; Pachiadaki et al., 2010).

To determine which factors mainly influence the composition of prokaryotic assemblages in mud volcano sediments, we carried out multivariate multiple regression analysis. We found that in all of the systems, $>80 \%$ of the total variance of the prokaryotic assemblage composition (as ratios between bacteria and archaea and crenarchaea and euryarchaea) was explained by the availability of trophic resources (in term of phytopigments, biopolymeric $C$ and $C$ released by the viral shunt) and by the 'viral predatory pressure' (that is, VIPM).

These findings suggest that the structure of the prokaryotic assemblages that inhabit these mud volcanoes is not only dependant on the geochemical features and processes of mud volcano ecosystems but also on synergic interactions with both bottomup (that is, available trophic resources for prokaryotic assemblages, including phytopigments) and top-down (that is, viral-mediated prokaryotic mortality) controlling factors.

Overall, our results highlight the significant roles of viral infection in mud volcano sediments for sustaining the metabolism of prokaryotes and for the shaping of their assemblage structure, and they provide new clues towards an understanding of cold-seep ecosystem functioning. 


\section{Acknowledgements}

This study was supported by the EU funded project HERMIONE and by the National Projects MESC (COFIN PRIN 2005) and EXPLODIVE (FIRB 2008, contract no. I31J10000060001). We would like to thank Dr M Magagnini for support in the field work and laboratory analyses.

\section{References}

Anderson MJ. (2001). Permutation tests for univariate or multivariate analysis of variance and regression. Can J Fish Aquat Sci 58: 626-639.

Anderson MJ. (2004). Dros. Inf. Serv. TLM, Version 5: A FORTRAN Computer Program to Calculate a DistanceBased Multivariate Analysis for a Linear Model. Department of Statistics. University of Auckland: Auckland, New Zealand.

Biddle JF, Lipp JS, Lever MA. (2006). Heterotrophic Archaea dominate sedimentary subsurface ecosystems off Peru. Proc Natl Acad Sci USA 103: 3846-3851.

Bonilla-Findji O, Malits A, Lefevrec D, Rochelle-Newall E, Lemee R, Weinbauer MG et al. (2008). Viral effects on bacterial respiration, production and growth efficiency: consistent trends in the Southern Ocean and the Mediterranean Sea. Deep-Sea Res II 55: 790-800.

Boetius A, Suess E. (2004). Hydrate Ridge: a natural laboratory for the study of microbial life fueled by methane from near-surface gas hydrates. Chem Geol 205: 291-310.

Corinaldesi C, Dell'Anno A, Danovaro R. (2007). Viral infection plays a key role in extracellular DNA dynamics in marine anoxic systems. Limnol Oceanogr 52: 508-516.

Corinaldesi C, Dell'Anno A, Magagnini M, Danovaro R. (2010). Viral decay and viral production rates in continental-shelf and deep-sea sediments of the Mediterranean Sea. FEMS Microbiol Ecol 72: 208-218.

Danovaro R. (2010). Methods for the Study of Deep-Sea Sediments, their Functioning and Biodiversity. CRC Press: Boca Raton.

Danovaro R, Corinaldesi C, Filippini M, Fischer UR, Gessner MR, Jaqchet S et al. (2008a). Viriobenthos in freshwater and marine sediments: a review. Freshwater Biol 53: 1186-1213.

Danovaro R, Corinaldesi C, Luna GM, Magagnini M, Manini E, Pusceddu A. (2009). Prokaryote diversity and viral production in deep-sea sediments and seamounts. Deep-Sea Res II 56: 738-747.

Danovaro R, Dell'Anno A, Corinaldesi C, Magagnini M, Noble R, Tamburini C et al. (2008b). Major viral impact on the functioning of benthic deep-sea ecosystems. Nature 454: 1084-1087.

Danovaro R, Dell'Anno A, Trucco A, Vannucci S. (2001). Determination of virus abundance in marine sediments. Appl Environ Microbiol 67: 1384-1387.

Danovaro R, Manini E, Dell'Anno A. (2002). Higher abundance of bacteria than viruses in deep Mediterranean sediments. Appl Environ Microbiol 68: 1468-1472.

del Giorgio PA, Cole JJ. (1998). Bacterial growth efficiency in natural aquatic systems. Annu Rev Ecol Syst 29: 503-541.

De Long EF, Taylor LT, Marsh TL, Preston CM. (1999). Visualization and enumeration of marine planktonic archaea and bacteria by using polyribonucleotide probes and fluorescent in-situ hybridization. Appl Environ Microbiol 65: 5554-5563.

Dell'Anno A, Corinaldesi C, Magagnini M, Danovaro R. (2009). Determination of viral production in aquatic sediments using the dilution-based approach. Nat Protocols 4: 1013-1022.

Dimitrov LI. (2002). Mud volcanoes - the most important pathway for degassing deeply buried sediments. Earth Sci Rev 59: 49-76.

Fuhrman JA. (1999). Marine viruses and their biogeochemical and ecological effects. Nature 399: 541-548.

Helton RR, Liu L, Wommack KE. (2006). Assessment of factors influencing direct enumeration of viruses within estuarine sediments. Appl Environ Microbiol 72: 4767-4774.

Hewson I, Fuhrman JA. (2007). Covariation of viral parameters with bacterial assemblage richness and diversity in the water column and sediments. Deep Sea Res I 54: 811-830.

Holland CW, Etiope G, Milkov AV, Michelozzi E, Favali P. (2003). Mud volcanoes discovered offshore Sicily. Mar Geol 199: 1-6.

Inagaki FT, Nunoura S, Nakagawa A, Teske M, Lever A, Lauer $M$ et al. (2006). Biogeographical distribution and diversity of microbes in methane hydrate bearing deep marine sediments on the Pacific Ocean Margin. Proc Natl Acad Sci USA 103: 2815-2820.

Jiao N, Herndl GJ, Hansell DA, Benner R, Kattner G, Wilhelm SW et al. (2010). Microbial production of recalcitrant dissolved organic matter: long-term carbon storage in the global ocean. Nat Rev Microbiol 8: 593-599.

Jørgensen BB, Boetius A. (2007). Feast and faminemicrobial life in the deep-sea bed. Nature Rev Microbiol 5: 770-781.

Joye SB, Boetius A, Orcutt BN, Montoya JP, Schulz HN, Erickson MJ et al. (2004). The anaerobic oxidation of methane and sulfate reduction in sediments from Gulf of Mexico cold seeps. Chem Geol 205: 219-238.

Karner MB, DeLong EF, Karl DM. (2001). Archaeal dominance in the mesopelagic zone of the Pacific Ocean. Nature 409: 507-510.

Kellogg CA. (2010). Enumeration of viruses and prokaryotes in deep-sea sediments and cold seeps of the Gulf of Mexico. Deep Sea Res II 57: 2002-2007.

Lipp SJ, Morono Y, Inagaki F, Hinrichs KU. (2008). Significant contribution of Archaea to extant biomass in marine subsurface sediments. Nature 454: 991-994.

Lösekann T, Knittel K, Nadalig T, Fuchs B, Niemann H, Boetius A et al. (2007). Diversity and abundance of aerobic and anaerobic methane oxidizers at the Haakon Mosby mud volcano, Barents Sea. Appl Environ Microb 73: 3348-3362.

Manini E, Luna GM, Corinaldesi C, Zeppilli D, Bortoluzzi G, Caramanna G et al. (2008). Prokaryote diversity and virus abundance in shallow hydrothermal vents of the Mediterranean Sea (Panarea Island) and the Pacific Ocean (North Sulawesi-Indonesia). Microb Ecol 55: 626-639.

Maugeri TL, Bianconi G, Canganella F, Danovaro R, Gugliandolo C, Italiano $\mathrm{F}$ et al. (2010). Shallow hydrothermal vents in the southern Tyrrhenian Sea. Chem Ecol 26: 285-298.

Michaelis W, Seifert R, Nauhaus K, Treude T, Thiel V, Blumenberg $\mathrm{M}$ et al. (2002). Microbial reefs in the Black Sea fueled by anaerobic oxidation of methane. Science 297: 1013-1015. 
Middelboe M, Glud RN, Wenzhöfer F, Ogurib K, Kitazato H. (2006). Spatial distribution and activity of viruses in the deep-sea sediments of Sagami Bay, Japan. Deep Sea Res I 53: 1-13.

Milkov AV. (2000). Worldwide distribution of submarine mud volcanoes and associated gas hydrates. Mar Geol 167: 29-42.

Niemann H, Lösekann T, de Beer D, Elvert M, Nadalig T, Knittel K et al. (2006). Novel microbial communities of the Haakon Mosby mud volcano and their role as a methane sink. Nature 443: 854-858.

Noble RT, Fuhrman JA. (1998). Use of SYBR green I for rapid epifluorescence counts of marine viruses and bacteria. Aquat Microb Ecol 14: 113-118.

Pachiadaki MG, Lykousis V, Stefanou EG, Kormas KA. (2010). Prokaryotic community structure and diversity in the sediments of an active submarine mud volcano (Kazan mud volcano, East Mediterranean Sea). FEMS Microbiol Ecol 72: 429-444.

Parkes RJ, Cragg BA, Banning N, Brock F, Webster G, Fry JC et al. (2007). Biogeochemistry and biodiversity of methane cycling in subsurface marine sediments (Skagerrak, Denmark). Environ Microbiol 9: 1146-1161.

Pernthaler A, Pernthaler J, Amann RI. (2004). Sensitive multi-color fluorescence in-situ hybridization for the identification of environmental microorganisms. In: Kowalchuk F, De Bruin J, Head IM, Akkermans ADL, Van Elsas JD (eds), Molecular Microbial Ecology Manual. Kluwer Academic Publishers: Dordrecht, The Netherlands, pp 711-726.

Pimenov NV, Rusanov II, Poglazova MN, Mityushina LL, Sorokin DY, Khmelenina VN et al. (1997). Bacterial mats on coral-like structures at methane seeps in the Black Sea. Microbiol 66: 354-360.
Pusceddu A, Dell'Anno A, Fabiano M, Danovaro R. (2009). Quantity and bioavailability of sediment organic matter as signatures of benthic trophic status. Mar Ecol Prog Ser 375: 41-52.

Savini A, Malinverno E, Etiope G, Tessarolo C, Corselli C. (2009). Shallow seep-related seafloor features along the Malta plateau (Sicily channel-Mediterranean Sea): morphologies and geo-environmental control of their distribution. Mar Petrol Geol 26: 1831-1848.

Schippers A, Neretin LN, Kallmeyer J, Ferdelman TG, Cragg BA, Parkes RJ et al. (2005). Prokaryotic cells of the deep sub-seafloor biosphere identified as living bacteria. Nature 433: 861-864.

Suttle CA. (2005). Viruses in the sea. Nature 437: $356-361$.

Suttle CA. (2007). Marine viruses-major players in the global ecosystem. Nature Rev Microbiol 5: 801-812.

Teira E, Reinthaler T, Pernthaler A, Pernthaler J, Herndl G. (2004). Combining catalyzed reporter deposition-fluorescence in-situ hybridization and microautoradiography to detect substrate utilization by Bacteria and Archaea in the deep ocean. Appl Environ Microbiol 70: 4411-4414.

Vetriani C, Jannasch HW, MacGregor BJ, Stahl DA, Reysenbach AL. (1999). Population structure and phylogenetic characterization of marine benthic Archaea in deep-sea sediments. Appl Environ Microbiol 65: $4375-4384$.

Williamson SJ, Cary C, Williamson KE, Helton RR, Bench SR, Winget D et al. (2008). Lysogenic virus-host interactions predominate at deep-sea diffuse-flow hydrothermal vents. ISME J 2: 1112-1121.

Wilhelm S, Suttle C. (1999). Viruses and nutrient cycles in the sea. Bioscience 49: 781-788.

Supplementary Information accompanies the paper on The ISME Journal website (http://www.nature.com/ismej) 